Revue Française de Civilisation Britannique

\title{
Review of Why Wales Never Was: the Failure of Welsh Nationalism by Simon Brooks
}

\section{Moya Jones}

\section{CpenEdition}

\section{Journals}

Electronic version

URL: http://journals.openedition.org/rfcb/2247

DOI: $10.4000 /$ rfcb.2247

ISSN: 2429-4373

Publisher

CRECIB - Centre de recherche et d'études en civilisation britannique

Electronic reference

Moya Jones, «Review of Why Wales Never Was: the Failure of Welsh Nationalism by Simon Brooks », Revue Française de Civilisation Britannique [Online], XXIII-2 | 2018, Online since 14 September 2018, connection on 02 May 2019. URL : http://journals.openedition.org/rfcb/2247 ; DOI : 10.4000/ rfcb.2247

This text was automatically generated on 2 May 2019.

\section{cc) $9 \odot$}

Revue française de civilisation britannique est mis à disposition selon les termes de la licence Creative Commons Attribution - Pas d'Utilisation Commerciale - Pas de Modification 4.0 International. 


\title{
Review of Why Wales Never Was: the Failure of Welsh Nationalism by Simon Brooks
}

\author{
Moya Jones
}

\section{REFERENCES}

Simon Brooks, Why Wales Never Was: the Failure of Welsh Nationalism, Cardiff: University of Wales Press, 2017, xvii+199 p., ISBN 978-1-78683-012-8

1 Simon Brooks is an independent academic and an author and a journalist, currently associated with the Morgan Academy, a research based think tank at the University of Swansea. This book was originally published in Welsh: Pam na fu Cymru - Methiant Cenedlaetholdeb Cymru, (Cardiff, UWP) in 2015 following his keynote lecture at the Llanelli National Eisteddfod, the previous year, in 2014. That speech was entitled "Twf cenedlaetholdeb Seisnig - cyfaill ta gelyn? /The Growth of English Nationalism - Friend or Foe?" in which he examined the notion of Welsh citizenship and in particular the place of the Welsh language in the civic nationalism model that has appeared in Wales over the past twenty years since the implementation of devolution. In the light of the then impending Scottish referendum on independence he examined Welsh identity, Welsh values and the fate of the Welsh language under the impact of all things English. These thoughts and arguments have been developed and extended in the present book as he attempts to understand the place of the Welsh language in Welsh citizenship, asking why the language has not flourished in devolved Wales. Simon Brooks lays the blame for the failure of Welsh nationalism in part on the Welsh people themselves and their leaders. "Nationalism was slain in Wales by liberalism, rather than conservatism, [...]. the Welsh nation was murdered by its own left-wing." (pp 143-4).

The book is composed of five chapters which examine the unexpected failure of the Welsh language. In the first chapter, entitled "An Unexpected Failure", he asks "Why isn't Wales 
a Welsh-speaking country today?" ( $\mathrm{p}$ 1) before attempting to analyse and explain this state of affairs, beginning in chapter 2 by comparing Wales to other small nations and noting the centrality of language to the mid- $19^{\text {th }}$ century struggles for independence in central Europe. In the third chapter, Liberalism, "so in tune with the Welsh in theological matters" ( $p$ 72), is revealed to be the tool of Welsh oppression and Liberal policies are consequently deconstructed in chapter 4 . The final chapter "When Will Wales Be?" is a clear reference to Gwyn Alf Williams' social history: When Was Wales? (London: Penguin, 1985) in which that author came to despairing conclusions about the way Wales was heading. The final chapter 6, entitled "Finis" is barely four pages long and while the nationalists of the past (distant and also those closer to the present) are singled out for their failure of ideas, their lack of ideology and for the prevalence of their self-doubt, Simon Brooks remains deeply pessimistic and condemns his contemporaries too: "But who are we in the twenty-first century to see the fault? For are we not as blind and as indifferent as they?" ( $p$ 144). Each chapter includes extensive, wide-ranging references and the index is pretty comprehensive.

3 Simon Brooks' basic premise is that there is an urgent need for in-depth, inclusive and sustained discussion on Welsh citizenship and he approaches the topic from the point of view of the predicament of Welsh speaking communities, which are still under threat. Simon Brooks' opinion is that this is still the case because language has always been associated with notions of 'ethnic nationalism', associated with the notions of philosophers such as Herder, who saw a nation as being based on cultural identity. This has therefore meant that the language has not been included in 'civic nationalism' notions that have dominated in Wales.

4 In order to put this argument into perspective we can remind ourselves of the information provided by the last census figures. Between 2001 and 2011, in Wales there was a decrease in the number and proportion of people aged 3 and over able to speak Welsh. Although the population of Wales has risen a little, the decrease in Welsh speakers has been due to demographic changes in the population, including fewer children, more older adults and the loss of older cohorts which had higher levels of Welsh speakers, migration and changes to people's skills between censuses. In 2011, 19\% of the population, about 562,000 people, declared they were Welsh-speaking. ${ }^{1}$ Nonetheless, while language considerations may have been the starting point for Dr Brooks' reflection, his conclusions are vitally important to Wales as a whole.

5 The author is a Welsh nationalist from a Labour party background. A founding member of and media spokesman for the Welsh language pressure group Cymuned, he re-joined Plaid Cymru when Leanne Wood was elected leader of the party. This helps us to comprehend his very strong critique of progressive politics, which, in Wales, was the key line of the Liberal party that dominated Welsh politics for so long and then was adopted by Labour. Brooks claims that these centralising progressive ideologies explain the debasement of Welsh culture and the Welsh nation.

6 He begins his historical analysis of Wales only in the mid- $19^{\text {th }}$ century by examining what was happening elsewhere in Europe, around 1848, when nations more or less comparable in size, and also undergoing industrialisation, (Hungary, Slovenia, Italy ...) in particular in the Habsburg Empire, were beginning to claim their national identity. The key difference between their stories of success and failure in Wales is because of the diglossia present in Wales, where English was always the language of progress and modernity. Elsewhere, "monolingualism did not lead to the curtailment of intellectual debate. On the contrary it 
led to a wave of modernity". ( $\mathrm{p}$ 47) Yet, being a nationalist did not prevent Welsh intellectuals from having wide cultural horizons, underpinned by world-wide travels.

7 In an unexpected defence of Toryism in Wales, Brooks sees $19^{\text {th }}$ century conservatism as potentially offering a way of maintaining a communitarian identity and of challenging the universalism of liberals and socialists. The notorious episode of the Blue Books, an extremely biased, and indeed racist, enquiry and report into education in Wales (1847) crushed self-confidence in Wales while promoting the prevailing view of progressive liberalism. For Simon Brooks, Welsh radicals and intellectual leaders capitulated when they accepted and adopted this narrative. The inferior Welsh would only progress once they were assimilated by the English.

is a counter narrative which Simon Brooks highlights which is that of the vision of nationhood developed and pursued by Michael D. Jones who set up the Welsh colony in Patagonia (1865). This non-conformist minister and nationalist was out of step with his period when he advocated nationhood for his country, recognising the detrimental effects of mainstream British culture and politics on his homeland. These days we talk of identity politics and Brooks sees contemporary theorists such as Miriam Iris Young as being the successors of activists such as Michael D Jones and Saunders Lewis.

This work is vigorously argued and has rocked the boat in Welsh political discussions which have been dominated by leftist and Labour politics for many years now. The author argues that Wales and the Welsh cannot continue to be tied to the old and now discredited ideologies that advocate so-called progressive policies. By mobilising social, political and intellectual theory he is asking awkward questions which, in a post-Brexit United Kingdom, may well need to be addressed. Contemporary Welsh nationalism has to be tackled afresh, with a broader vision.

\section{NOTES}

1. https://gov.wales/docs/statistics/2012/121211sb1182012en.pdf consulted 25 May 2018

\section{AUTHORS}

\section{MOYA JONES}

Université Bordeaux Montaigne 